IDEA - Studia nad strukturą i rozwojem pojęć filozoficznych

\title{
TRANSLATORIUM
}

\section{IMMANUEL KANT}

\section{O NIEMOŻLIWOŚCI \\ ONTOLOGICZNEGO ARGUMENTU NA ISTNIENIE BOGA}

\author{
Z języka tacinskiego przetożyt, wstepem i przypisami opatrzyt \\ Jacek Surzyn
}

\section{Od tłumacza}

Krytyka czystego rozumu Immanuela Kanta wydaje się dziełem przełomowym, ponieważ trudno wyobrazić sobie współczesny dyskurs filozoficzny (obojętnie o jakim stanowisku i poglądach filozoficznych myślimy) nie odnoszący się do tego dzieła. W Krytyce... Kant dokonał sławnego „przewrotu kopernikańskiego”, który w pierwszym rzędzie i w powszechnym mniemaniu dotyczył fundamentalnej zmiany w postrzeganiu ludzkiego poznania, ale po głębszej analizie ukazuje się również jego kapitalne znaczenie dla ontologii, czy metafizyki w ogóle. Kant zresztą buduje swą narrację w Krytyce... wokół próby odpowiedzi 
na pytanie o naukowy status metafizyki, czy też inaczej mówiąc o możliwość metafizyki jako takiej. Wskazuje na wielki „metafizyczne skandal”, który odzwierciedla dotychczasową kondycję tej, zdawałoby się, królowej nauk. Krytyczny namysł Kanta miał zmienić niekorzystny obraz dotychczasowych dociekań metafizycznych.

Jednym $z$ wymiarów wskazanego kryzysu jest dla Kanta stan rozważań nad najwyższą istotą, Bogiem, rozważań składających się z wielowiekowych dysput teologicznych. Teologia ujmowana przez Kanta jako racjonalna, jest jedną z trzech części tradycyjnej metafizyki, którą nazywa on metaphysica specialis. Jak wiadomo poza racjonalną teologią tworzą ją racjonalna psychologia i racjonalna kosmologia. Właśnie problematyka dotycząca najwyższej istoty-Boga odwołuje zarówno do teologii, jak i częściowo do kosmologii. Kant ma tu na myśli przede wszystkim dociekania dotyczące dowiedzenia istnienia (realnego) takiej istotyBoga. Dowód (dowody) na istnienie Boga od stuleci przykuwały uwagę myślicieli i teologów, jednak stały się dla królewieckiego filozofa niemal podręcznikowym przykładem jałowości tradycyjnych dociekań metafizycznych wynikających z jej kiepskiego naukowego stanu. Wśród dowodów na istnienie Boga jeden wysuwa się na pierwsze miejsce i swą siłą przyćmiewa wszystkie pozostałe. Jego autorem jest św. Anzelm z Canterbury, a od czasów Kanta (zresztą głownie dzięki niemu) nazywany jest dowodem ontologicznym. Od razu należy wskazać na do dziś powielane nieporozumienie w przypadku dowodu Anzelma: nieporozumieniem jest zupełnie nierozważne i nierzetelne klasyfikowanie pomysłu Anzelma jako dowodu. Jeśli wczytamy się w Anzelmowy wywód w wersji źródłowej, to zrozumiemy, że autorowi nie chodziło o wykazanie w ścisłym dowodowym sensie istnienia Boga, zdecydowanie nie próbował przeprowadzić dowodu. Anzelm wielokrotnie podkreślał, że nie formułuje żadnego dowodu na istnienie Boga, bo takowy uważa za niemożliwy i zupełnie zbędny z perspektywy wierzącego człowieka. Zależało mu tylko na wzmocnieniu wiary za pomocą jednego argumentu, który byłby nie do obalenia przez rozumową argumentację. Anzelm za pomocą dowodu realizuje więc postawiony przez siebie i stanowiący podstawę średniowiecznej scholastyki postulat „wiary poszukującej zrozumienia” - fides quaerens intellectum. Dowód Anzelma powinno się zatem - idąc za jego wskazówką - określać jako unum argumentum, czyli próbę wskazania jednej, wystarczającej racji za istnieniem Boga (ratio Anselmi), które wzmocni, ale nie zstąpi wiary w Boże istnienie. Czasy późniejsze wzmocniły jednak tylko racjonalną część argumentacji Anzelma przekształcając ją w czysto rozumowy dowód słu- 
żący bezwzględnemu wykazaniu istnienia Boga bez odwoływania się już do jakiegoś związku z wiarą. Dowód w takim kształcie przyjął Kartezjusz, traktując rację Anzelma czysto rozumowo i przy okazji w decydujący sposób przekształcając istotę argumentacji autora. W przypadku tej wersji należy raczej mówić o nowym dowodzie, choć zachowującym Anzelmowy kierunek wykazywania istnienia od myślnie ujętej istoty bytu najwyższego (najdoskonalszego) do konieczności jego (bytu) realnego istnienia. Wydaje się, że właśnie tak kontekst ontologicznego dowodu rozumiał Kant i w tym ujęciu w Krytyce... wykazywał jego niemożliwość. Argumentacja Kantowska odnosi się wyłącznie do nieprawomocności przechodzenia od możliwości pomyślenia bytu absolutnego (bytu najwyższego) do konieczności jego realnego istnienia w imię zachowania logicznej poprawności wynikającej z założenia absolutnej natury, a więc wykluczającej wszelki brak (w tym brak wszelkiego istnienia). Sławne przy tym pozostaje twierdzenie Kanta, że istnienie (bycie) nie jest żadnym atrybutem rzeczy, który przynależy do niej na zasadzie właściwości, zatem w konsekwencji nie sposób w oparciu o treść pojęcia uznać jego pozamyślne, dodatkowo w tym przypadku (bytu absolutnego) konieczne, realne istnienie.

Przygotowany tekst przekładu dotyczy fragmentu Krytyki czystego rozumu zamieszczonego w trzeciej części czwartego rozdziału zatytułowanego $O$ niemożliwości ontologicznego dowodzenia istnienia Boga. Tekst jest świetnie znany, a zawarty w nim dowód ontologiczny doczekał się wielu komentarzy i opracowań. Niektóre fragmenty tekstu stały się niemal znakami rozpoznawczymi filozofii Kantowskiej, na przykład sławny przykład ze stoma talarami. Oczywiście tekst znany jest $\mathrm{z}$ oficjalnego niemieckiego oryginału Krytyki..., jednak obecnie chciałbym zaproponować przekład rzeczonego fragmentu z niezwykle ciekawej, ale słabo znanej łacińskiej wersji Krytyki czystego rozumu. Łaciński tekst Krytyki... był pierwszym przekładem tego dzieła, a autor to Fryderyk Gottlieb Born, niezwykle aktywny propagator filozofii Kanta i profesor uniwersytetu w Lipsku jeszcze za życia filozofa. Postać Borna skrywa się w cieniu Kanta, ale warta jest przybliżenia, podobnie myślę o łacińskim przekładzie, który postaram się przedstawić. Fryderyk Gottlieb Born stał się w latach 1780-1790 entuzjastą filozofii krytycznej królewieckiego mistrza i przełożył wiele jego tekstów, przekład na łacinę Krytyki... miał być kolejnym milowym krokiem w upowszechnianiu tej wiedzy. Łacina w tamtych czasach nadal pozostawała językiem nauki i filozofii, mimo skutecznych prób wypierania jej przez języki narodowe. W wyborze języka przekładu mieści się niemała wartość, ponieważ łacina scholastyczna przez 
całe stulecia pełniąc rolę języka filozoficznego dyskursu wypracowała całą strukturę filozoficznych terminów, których właściwe oddanie w językach nowożytnych (narodowych) sprawiało prawdziwe trudności. Ale faktem było również $\mathrm{w}$ owych czasach bardzo twórcze zderzanie się filozofii uprawianej w łacinie $\mathrm{z}$ filozofią wyrażaną w innych językach. Owo napięcie dobrze widać, kiedy bada się zakres terminologii, którą filozofowie wtedy wypracowywali. Kant nie był wyjątkiem i napisanie Krytyki czystego rozumu w języku niemieckim okazało się niemal decydujące dal ukształtowania niemieckiego języka filozoficznego. Fryderyk Born, chcąc rozpowszechnić dzieło Kanta podjął decyzję ujęcia Krytyki... w ramy tradycyjnej, scholastycznej łaciny, choć w wymiarze konstrukcyjnej od niej już odchodził. W tekście Borna najważniejsza wydaje się właśnie terminologia i na tym skupiłem uwagę przystępując do pracy. Przekładając fragment Krytyki... pod tytułem O niemożliwości ontologicznego argumentu na istnienie Boga, starałem się oddać czystą scholastyczną terminologię zawartą w przekładzie Borna.

O Fryderyku G. Bornie, autorze łacińskiego przekładu należy powiedzieć, że żył w latach 1743-1807. Urodził się i zmarł w Lipsku, który był jego rodzinnym miastem. Od roku 1785 pracowal jako profesor na uniwersytecie w Lipsku. Redagował magazyn filozoficzny pod tytulem Neues philosophisches Magazin (nie należy mylić tego periodyku z wydawanym przez jednego z pierwszych krytyków koncepcji Kanta J. A. Eberharda). Zaskakująco niewiele wiadomo o kontaktach między królewieckim filozofem a Bornem - między majem 1786 roku a majem 1790 roku prowadzili z sobą korespondencję, jednak nie zachował się żaden list Kanta do Borna. Fryderyk G. Born przełożył na łacinę grupę tekstów Kanta, które wydał pod ogólnym tytułem Immanuelis Kantii Opera ad philosophiam criticam (Leipzig, 1796-1798). Jest także autorem kilku dzieł filozoficznych częściowo odnoszących się do różnych aspektów Kantowskiej filozofii. Lista najważniejszych jego dzieł przedstawia się następująco: Versuch über die ersten Gründe des Sinnen Lehre: Zur Prüfung verschiedner, vornämlich der Weishauptischen Zweifel über die Kantischen Begriffe von Raum und Zeit (1788), [Reprint: Bruxelles 1970, w: Aetas Kantiana, vol. 38]; Versuch über die ursprünglichen Grundlagen des menschlichen Denkens und die davon abbängigen Schranken unserer Erkenntniss (Leipzig, 1791) [Reprint: Bruxelles 1969, w: Aetas Kantiana, vol. 39]; Lexicon Latinum et Theodiscum ad forman kirschiani cornv copiae (Leipzig, 1790); Neues philosophisches Magazin: Erläuterungen und Anwendungen des Kantischen Systems bestimmt (Leipzig, 1790), 2 vol. [Reprint: Bruxelles 1970, w: Aetas Kantiana, vol. 5]. 


\title{
Immanuel Kant
}

\author{
Krytyka czystego rozumu ${ }^{1}$ \\ Część Trzecia \\ Sekcja Czwarta \\ O niemożliwości ontologicznego argumentu \\ na istnienie ${ }^{2}$ Boga
}

\section{2}

$\mathrm{Z}$ tego, co dotychczas stwierdziliśmy, łatwo można zrozumieć, że pojęcie natury absolutnie koniecznej jest czystym pojęciem racjonalnym, to znaczy jedynie ideą, która posiada realność obiektywną z tego, że rozum jej potrzebuje, a żadnym sposobem nie jest dowiedziona, zaś jedynie do pewnej nieosiągalnej doskonałości jest sprowadzona i właściwie raczej nakłania, aby rozumowanie (intelekt) do tego, co ograniczone ograniczyć, niż aby go do obiektów rzeczy nowych doprowadzać. Wydaje się, że owo sytuowanie tej (idei) słusznie jest dziwne i obce, ponieważ wnioskowanie od jakiegoś istnienia danego w świecie do jakiegoś istnienia absolutnie koniecznego jest mocne i wydaje się zawierać

${ }^{1}$ Tłumaczenie z wydania: Immanuelis Kantii Opera ad philosophiam criticam.Volumen primum cui inest "Critica rationis Purae”, latine vertit F. G. Born, Lipsiae 1796, s. 411-418.

${ }^{2} \mathrm{~W}$ tekście czytamy: pro existentia Dei. Born użył zatem terminu existentia, który jednak nie był powszechnie stosowany w łacinie scholastycznej, gdyż bardziej odnosił się do stworzenia niż Boga. Tomasz z Akwinu na przykład praktycznie w ogóle go nie używał. O istnieniu Boga pisał zawsze stosując termin esse. Specyficzne rozróżnienie na tym gruncie wprowadził Jan Duns Szkot. Pojęcie existentia przyjęło się od czasu Henryka z Gandawy, który wskazywał na różnicę pomiędzy esse existentia i esse essentia. Rozróżnienie to podtrzymał Idzi Rzymianin i chyba on je rozpowszechnił. W czasach Kanta nie wskazywano już na rozróżnienie esse i existere i raczej w językach nowożytnych zaczęto ich używać synonimicznie. Problemem samym w sobie pozostaje kwestia rozumienia istnienie przez samego Kanta. W niemieckim oryginale „Krytyki...” Kant użył tu słowa Dasein. 
w sobie prawdę, podczas jednak wszystkie uniwersalne prawa rozumowania, które kształtują tego typu konieczne pojęcie mamy całkowicie przeciwko sobie.

Czynili tak i czynią ci, którzy o naturze absolutnie koniecznej rozprawiają, chociaż mało ku temu się kierowali, aby zrozumieć, czy i w jaki sposób tego typu rzecz lub sposób pomyślenia można byłoby osiągnąć, a wiele wysiłku wkładali w udowodnienie jej istnienia. Wprawdzie definicja słowna tego pojęcia jest łatwa (do ukazania), mianowicie ujawnia się w tym, że jako nie będącą, nie można jej uczynić; jednak faktycznie rzecz ta w żaden sposób nie sprawia, że stajemy się mądrzejsi odnośnie do rozumowych warunków, które wskazują jako możliwe rzecz nie istniejącą jako coś, czego pomyślenia nie sposób uznać, co właściwie jest tym, co wiedzieć chcemy, mianowicie czy przez to pojęcie coś w ogóle pojmowanego osiągamy, czy też nie. Bowiem jeśli powszechne warunki, które zawsze są wymagane przez rozsądek, aby coś jako konieczne zostało określone za pomocą słowa „absolutny” odrzucać, to w żaden jeszcze sposób nie sprawia, że zrozumiem, czy takie pojęcie czegoś absolutnie koniecznego z tego w jakoś pojmuję, czy też zgoła niczego poprzez to nie myślę.

Cóż więc? $\dot{Z}$ e to pojęcie uzyskane wyłącznie na drodze przypadku (fortuny), choć szeroko używane, mnóstwem przykładów zdaje się objaśniają, tak że wszelkie dalsze badanie jego rozumienia (znaczenia) wydaje się być zbędne. Każde twierdzenie geometryczne, na przykład że trójkąt posiada trzy kąty, jest po prostu konieczne, i podobnie faktem pozostaje, aby mówić o rzeczy, która sytuuje się całkowicie poza sferą naszego rozsądku, jak gdyby pewnie było uzmysłowione, co chce się z jego pojęcia o niej stwierdzić.

Wszystkie zaś te przemyślane przykłady bez jakiegokolwiek wyjątku zostały wywiedzione $z$ sądów, a nie $z$ rzeczy i ich istnienia. Lecz absolutna konieczność sądów nie jest absolutną koniecznością rzeczy. Bowiem konieczność absolutna sądu jest jedynie w jakiś sposób od warunku uzależnioną koniecznością rzeczy, czyli od orzekania w sądzie. Twierdzenie powyżej przytoczone nie stwierdzało, że trzy kąty są absolutnie konieczne, lecz tylko pod warunkiem, że jeśli trójkąt jest (jest dany), to trzy kąty są (w nim) konieczne. Niemniej owa konieczność logiczna niesie w sobie tak wielką moc iluzji, że pojęcie w jakiś sposób uformowane $z$ antycypowania rzeczy, tak zostało ukonstytuowane, aby według naszego mniemania zawierało $\mathrm{w}$ swoim zakresie również istnienie, a wtedy $z$ tego pewny wniosek można przyjąć, że pewnej rzeczy takiego pojęciowanego podmiotu ko- 
niecznie przysługuje istnienie ${ }^{3}$, to znaczy przy założeniu, że taką rzecz jako daną (istniejącą) przyjmuję, także konieczne jej istnienie (w oparciu o zasadę tożsamości) zostaje przyjęte. Tym samym natura ta sama jest właściwie absolutnie konieczna, jeśli pewne jej istnienie zostało już zaakceptowane w dowolnie przyjętym pojęciu i pod warunkiem, że również jako jej rzecz przyjmuję jakiś podmiot.

Jeżeli w sądzie tożsamościowym zatrzymuję podmiot i usuwam orzeczenie, skutkuje to sprzecznością, i dlatego stwierdzam: ono przysługuje temu w sposób konieczny. Jednak kiedy usuwam jakiś podmiot razem z orzeczeniem, wówczas żadną sprzecznością to nie skutkuje, bowiem nie pozostanie coś, w czym mogłaby zajść sprzeczność. Przyjmowanie trójkąta i zarazem odrzucanie jego trzech kątów jest niedorzecznością. Lecz usunięcie jakiegoś trójkąta razem z jego trzema kątami nie powoduje niedorzeczności. Podobnie dzieje się z pojęciem natury absolutnie koniecznej. Jeśli usuniecie jego istnienie, usuniecie rzecz samą z jej wszystkimi atrybutami; skąd jednak pojawia się sprzeczność? Na zewnątrz nie istnieje nic, w czym pojawiłaby się sprzeczność, jeśli jakaś rzecz nie posiada na zewnątrz koniecznego istnienia; nie ma też czegoś wewnątrz, ponieważ usuwając rzecz samą, tym samym usunęliście wszelką wewnętrzność. Bóg jest wszechmocny jest to sąd konieczny. Wszechmocy nie można usunąć, gdy

${ }^{3} \mathrm{~W}$ tym miejscu tekstu pojawia się termin esse. Należy tu od razu odnieść się do kwestii rozumienia istnienia przez Kanta. Kant wyraźnie oddziela dwa pojęcia, które stosuje na określenie istnienia. W języku niemieckim są to Existenz i Dasein. W tytule tego tekstu mamy termin Dasein, w tekście występuje także Existenz, ale także trzeci termin Position. Istotą rozumowania Kanta było rozróżnienie poznania zmysłowego i intelektualnego, co sprowadza się do określenia dwóch źródeł poznania: receptywności i spontaniczności (samorzutności). Najkrócej mówiąc, Dasein $\mathrm{w}$ „Krytyce czystego rozumu” odnosi się do istnienia przedmiotu, który oddziałuje na nasze zmysły (bezpośrednio, lub pośrednio). W rozważanym tu kontekście kant naturalnie używa więc terminu Dasein w odniesieniu do istnienia Boga, ponieważ nie rozważa tu Boga transcendentnego, istniejącego gdzieś w zaświatach, ale raczej uobecnienie się Boga tu na ziemi za pomocą wpływu na wszystko, co istnieje. Dasein dokładnie to oddaje, ponieważ jest złożenie da jako „tu, oto, teraz” $\mathrm{z}$ byciem, istnieniem - sein. Zatem „tu oto bycie”, oznacza uobecnienie. Termin Existenz oddaje $\mathrm{z}$ kolei istnienie konieczne, ale $\mathrm{w}$ sensie logicznym, jak w przypadku wyznaczania istnienie, lub nieistnienia czegoś ze względu na prawa logiki. Do takiego istnienia dochodzi wyłącznie intelekt, zatem różni się ono od istnienia empirycznego. Dowody, czy też argumenty za istnienie Boga nie pełnią zdaniem Kanta, takiej funkcji logicznej, lecz właśnie zakorzenione są w realności, w rzeczach, jak pisze. Stąd ontologiczny dowód, czy tez argument musi dotyczyć empirycznego istnienie Boga, a nie jego istnienia logicznego. Niemożliwość takiego istnienia wynika właśnie z wymieszania tych dwóch porządków. 
przyjmujecie boskość, to znaczy nieskończoną naturę, z której pojęciem to jedno jest identyczne. Jednak jeśli stwierdzisz: Bóg nie istnieje, to wówczas nie istnieje ani wszechmoc, ani jego jakiś atrybut, ani też jakieś powszechniki z tym podmiotem związane. Ponieważ wraz z podmiotem zostały usunięte. I w rozumowaniu takim nie ma nawet najmniejszej niezgodności.

Zobaczyliście zatem, że jeśli usuwam orzeczenie jakiegoś sądu razem z podmiotem, nigdy tu nie może zaistnieć wewnętrzna niezgodność, przy jakimkolwiek orzeczeniu. Nie macie więc wyjścia, tylko musicie stwierdzić: istnieją podmioty, których w żaden sposób nie można usunąć, które zatem są zobowiązane do pozostania. A znaczy to tyle, że istnieją absolutnie konieczne podmioty, co jest pewnym założeniem, w którego prawdę powątpiewałem, a którego możliwość wy chcieliście mi wykazać. Nie mogę bowiem osiągnąć nawet w minimalnym stopniu wiedzy o rzeczy, która usunięta razem ze swoimi powszechnymi atrybutami pozostawiła jakąś niezgodność, a bez owej niezgodności nie mam w żaden sposób niemożliwości uzyskanej w oparciu o same czyste pojęcia wyzyskane $z$ antycypacji.

Przeciwko tym wszystkim argumentom (których żaden człowiek nie może obronić) prowokujecie mnie przez jakiś przypadek, który mi przedstawiacie jako pewien argument o fakcie, mianowicie, że istnieje przecież pewne pojęcie i tylko ono jedno, w którym usunięcie jego przedmiotu jest samo w sobie niezgodne, a jest nim pojęcie natury najdoskonalszej (bytu najrealniejszego). Ma w sobie, jak twierdzicie, całą realność, i możecie słusznie uznać możliwość istnienia takiej natury (co teraz przyjmuję, chociaż nie jest wykazane, aby pojęcie sprzeczne z sobą nie mogło być rzeczą obiektywną). Ale w całkowitej realności jest zawarte również istnienie, zatem istnienie tkwi w pojęciu tego, co może istnieć. Jeżeli zatem zostanie usunięta owa rzecz, to zostanie również usunięta jej wewnętrzna możliwość, co wywołuje sprzeczność.

Mam na to odpowiedź: popadliście już w sprzeczność, gdy w pojęcie rzeczy, którą chcecie pomyśleć wyłącznie na podstawie jej możliwości, pod jakąś

${ }^{4}$ „Pojęcie zawsze może istnieć, gdy samo nie jest sprzeczne. Ujawnia się w tym oczywista logiczna możliwość i ona odróżnia rzecz tego podmiotu od nicości negatywnej. Jednak może ono być pustym pojęciem, wtedy gdy nie wykażemy przedmiotowej realności syntezy, przez którą dane pojęcie się tworzy. Jednak, jak wykazałem, taki argument zawsze jest związany z zasadami możliwego doświadczenie, a nie wynika ze sprzeczności. Jest to przestroga, aby z logicznej możliwości nie wnosić o możliwości realnej (obiektywnej)". Jest to przypis zamieszczony w tekście przez Kanta. 
ukrytą nazwą wprowadziliście już pojęcie jej istnienia. Gdy ktoś zgodzi się $\mathrm{z}$ wami, to niby coś wygraliście, ale w rzeczy samej nic nie powiedzieliście, gdyż skonstruowaliście jedynie tautologię. Pytam was zatem, czy owo stwierdzenie: ta lub inna rzecz (którą, podobnie jak wy, uważam, jakakolwiek ona jest, za możliwą) istnieje, czy też, zaznaczam, że to stwierdzenie jest analityczne czy syntetyczne? Jeśli jest analityczne, to przez istnienie rzeczy nic nie jest dodane do waszego myślenia o rzeczy, ale wtedy słusznie myśl, która jest w was, albo musiałaby być w rzeczy nią samą, albo założyliście wcześniej istnienie, jako przynależne do możliwości, a następnie jak twierdzicie, wywnioskowaliście je z możliwości wewnętrznej, co nie jest niczym innym, jak marną tautologią. Słowo „realność”, które w pojęciu rzeczy brzmi inaczej niz "istnienie" ${ }^{5} \mathrm{w}$ pojęciu orzeczenia nic nie daje. Bowiem jeśli wszelkie usytuowanie ${ }^{6}$ (bez względu na to, co twierdzicie) nazywacie realnością, to już rzecz jakąś razem z wszystkimi jej atrybutami w pojęciu podmiotu stwierdziliście i uznaliście za prawdę w rzeczy, nic innego nie wnosząc do atrybutów jak tylko powtarzając to, co już tam w jakiś sposób tkwi. Przeciwnie, jeśli trzeba przyjąć, co musi uznać każdy zdrowy na umyśle, że wszelkie twierdzenie egzystencjalne jest syntetyczne, to jakim sposobem utrzymujecie, że atrybutu istnienia nie można usunąć bez sprzeczności, gdy owa szczególna właściwość przysługuje wyłącznie twierdzeniom analitycznym, co do których wydaje się, że ich wyjątkowa natura tym właśnie się wyróżnia?

Zacząłem już mieć nadzieję owe subtelności przebiegłe w niwecz obrócić nazywając wprost dokładnym określeniem pojęcia istnienia, dokładnym określeniem pojęcia istnienia, gdyby nie przekonanie, że iluzja pomieszania atrybutu logicznego $\mathrm{z}$ innym realnym (to znaczy $\mathrm{z}$ określeniem jakiejś rzeczy), niemal wymyka się wszelkim regułom i próbom naprawy. Atrybutem logicznym może być wszystko, co się chce, nawet sam podmiot może być swoim atrybutem, jeśli z założenia logika abstrahuje od wszelkiej materii. Jednak treść (określenie) wydaje się być orzeczeniem (atrybutem), które przekracza właściwe pojęcie podmiotu i je powiększa. Zatem konieczne jest, że ono nie zawiera się w nim.

Dowiedzione zostało, że istnienie nie jest żadnym orzeczeniem (atrybutem) realnym, to znaczy, w pojęciu czymś, co mogło zostać dodane do pojęcia jakiejś

${ }^{5} \mathrm{~W}$ niniejszym przekładzie Born wstawił tu słowo existentia i warto zaznaczyć, że w oryginale niemieckim mamy Existenz, co wydaje się zrozumiałe w świetle przedstawionego wcześniej rozróżnienia Kanta.

${ }^{6} \mathrm{~W}$ tłumaczeniu czytamy: si vel omnem positionem. Born użył zatem słowa positione, które ma oddać pojawiający się tu u Kanta niemiecki termin Setzen. 
rzeczy. Widać, że ono tylko stwierdza coś w pozycji ${ }^{7}$ rzeczy lub stwierdza pewne określenia, które są same przez się. W użyciu logicznym jest jedynie łącznikiem w sądzie. Twierdzenie: Bóg jest wszechmocny, zawiera dwa pojęcia, które jako rzeczy mają swoje podmioty: raz Boga, raz wszechmoc; słowo: ,jest” nie stanowi jakiegoś atrybutu, lecz w nim tylko mieści się stan atrybutu [odniesienie atrybutu] względem podmiotu. Jeśli więc biorę podmiot (Bóg) z wszystkimi jego atrybutami (wśród których jest także wszechmoc) i twierdzę: „Bóg jest” lub: „jest jakiś Bóg”, to nie dołączam żadnego nowego atrybutu do pojęcia Boga, lecz przyjmuje jedynie podmiot przez się jako sam w sobie razem $z$ wszystkimi jego atrybutami, i pewną rzecz obiektywną w odniesieniu do mojego pojęcia. Oba powinny zawierać tę samą treść, a zatem do pojęcia, które wyraża tylko możliwość, to że pomyślę rzecz jego obiektywną jako w prosty sposób daną, gdy powiem: ,jest”, niczego innego nie można wnieść. I tak ono istniejąc zawiera tylko to, że może istnieć. Liczba stu Joachimów ${ }^{8}$ w rzeczywistości (lub realnie) nie zawiera ani odrobiny czegoś więcej od stu pomyślanych fikcyjnie i możliwych. Jeśli bowiem te [pierwsze] oznaczają tylko pojęcie, to tamte rzecz samą ujętą pod pojęciem podmiotu i jego usytuowaniem przez siebie samego, gdyby więc to (co tu rozważam) zawierałoby w sobie więcej w rzeczy niż w tym pojęciu, to wówczas moje pojęcie nie wyrażałoby całości tej rzeczy proponowanej, a więc również nie byłoby pojęciem odpowiadającym tej rzeczy. Jednak w mojej sytuacji, jeśli posiadam sto realnych Joachimów, to znaczy więcej niż jedynie to, że w jakiś sposób mam myśl o nich (to jest o ich możliwości). Bowiem wobec pojęcia podmiot rzeczy, jeśli on naprawdę w niej tkwi i go wyraża, to nie tylko jest zawarty analitycznie w pojęciu, lecz dochodzi syntetycznie do pojęcia (które w określonych warunkach jest moje), chociaż poza moim pojęciem same owe sto Joachimów, pomyślane w odniesieniu do tych realnych, niczego nie powiększa ani nie zmienia.

Jeżeli zatem pomyślę jakąś rzecz za pomocą wielu jakichkolwiek atrybutów (w samym określeniu doskonałą), to dzięki temu, że dodam jej, że ta rzecz istnieje, niczego nawet w minimalnym stopniu nie dokłada się do rzeczy. Inaczej

\section{${ }^{7}$ Mamy tu: in positione rei.}

${ }^{8}$ Zdecydowałem się na to określenie, choć chodzi oczywiście o talary iw oryginale niemieckim Kant o talarach pisze. Polskie określenie „talar” jest skróconą postacią niemieckiego Joachimsthaler Gulden (czyli „złoty joachimstalski”). Nazwa ta pochodzi od miejscowości czeskiej Joachimsathal, gdzie w roku 1519 hrabiowie Schlick zaczęli bić takie srebrne monety. Stały się one powszechnym środkiem płatniczym niemal w całej Europie. 
bowiem istniałoby coś innego, nie to samo, lecz coś więcej niż pomyślałbym w pojęciu, nie mógłbym też stwierdzić, że sama rzecz jako podmiot mojego pojęcia istnieje. Jeśli nawet naturę pomyślę jako najwyższą realność (bez braku), to jednak zawsze pozostaje kwestia, czy ona istnieje, czy też nie. Tak jak bowiem w moim pojęciu, które może istnieć, materia jakiejś rzeczy w ogólności niczego nie wnosi, tak daje coś w odniesieniu do powszechnych moich pomyślanych warunków, mianowicie poznanie pewnej rzeczy z przedmiotu zgodne z możliwym użyciem i doświadczeniem. W tym jeszcze manifestuje się przyczyna ciągłej trudności w tej rzeczy. Jeśli zatem mówiło się o rzeczy zmysłowej bez kontekstu, to nie mógłbym istnienia rzeczy z samym tylko pojęciem rzeczy pomieszać. Bowiem pomyślane pojęcie rzeczy obiektywnej może istnieć tylko zgodnie z powszechnymi warunkami poznania [pomyślenia] empirycznego w ogóle. Wprawdzie, dzięki połączeniu z materią całego doświadczenia, pojęcie rzeczy nie powiększa się ani niczego nie pozyskuje, jednak myślenie nasze zyskuje możliwość tego postrzeżenia [takiej percepcji]. Przeciwnie zaś, gdy chcielibyśmy istnienie pomyśleć tylko z czystej kategorii, to nie jest dziwne, że nie możemy wskazać żadnej cechy, dzięki której dałoby się oddzielić ją od jedynie możliwości.

Gdyby więc nie wiadomo co i ile zawierałoby pojęcie naszej rzeczy o jakimś przedmiocie, to jeszcze jest konieczne, jak to zakładamy, aby tej rzeczy przyznać istnienie. Wobec czegoś w rzeczach, które podpadają pod zmysły, jest to skutkiem połączenia $\mathrm{z}$ jakąś naszą percepcją praw empirycznych. Ale odnośnie do rzeczy jako podmiotów czystego myślenia nie ma żadnego właściwego sposobu poznania ich istnienia, gdyż właściwie należałoby je wywieść $\mathrm{z}$ antycypacji samego myślenia. Po prawdzie zaś nasza prawiedza jakiegokolwiek istnienia (uzyskana przez bezpośrednią percepcję czy też przez wnioski, które wiążą coś z percepcją) całkowicie przynależy do jedności doświadczenia i trudno znaleźć jakieś osadzenie dla pewnego istnienia leżącego poza obszarem tego pola, chociaż nie może być po prostu uznane za niemożliwe, ale nie może tak po prostu być uznane za niemożliwe, tylko uznane za przypuszczenie, którego nie możemy niczym wykazać ani usprawiedliwić. Pojęcie najwyższej natury jest ideą w różnych aspektach bardzo pożyteczną, jednak w odniesieniu do samej rzeczy, to że jest jedynie ideą nie przydaje się, aby wyłącznie dzięki niej poszerzać nasze pojmowanie tych treści, które istnieją. Ona nawet tyle nie zdziała, aby w oparciu o treść tego, co może istnieć, pouczyć nas o czymś więcej. 
Analityczna cecha możliwości, która w tej [naturze] jest zawarta, wskazująca, że same upozycjonowania (realności) ${ }^{9}$ nie generują żadnej sprzeczności, nie może być jemu nie przyznana; lecz skoro powiązanie wszystkich realnych atrybutów w jakiejś rzeczy skutkuje syntezą, o możliwości której nie możemy sądzić $\mathrm{z}$ antycypacji, ponieważ nie są nam realności dane szczegółowo, a gdyby nawet to przyjąć, to żaden sąd nie byłby w tej sytuacji możliwy, bo pewne cechy możliwości poznań syntetycznych jako używanych szukać trzeba zawsze tylko w doświadczeniu, do którego zaś podmiot rzeczy idei nie może wszak przynależeć. Dlatego przesławny Leibniz wcale nie uczynił tego, co sobie chwalebnie mniemał, to znaczy chcąc taką wzniosłość wyprowadzić z antycypacji możliwość natury idealnej.

Przy okazji zatem tego sławnego argumentu ontologicznego (kartezjańskiego), dotyczącego wykazania istnienia najwyższej natury z pojęć, wszelki wysiłek i praca okazały się daremne i nikt $z$ samych tylko idei nie wzbogaci się $\mathrm{w}$ wiedzę, podobnie jak kupiec w majątek, gdyby dla poprawy swego położenia zechciał do stanu swego posiadania dopisać kilka zer.

\footnotetext{
${ }^{9}$ Born pisze: positionibus (realitatibus). Kant w oryginale pisze: Positionen (Realität). Chodzi więc o istnienie, ale rozumiane w szerokim znaczeniu usytuowania i odniesienia, które owo istnienie determinuje. Stąd takie istnienie jest realnością. Nieco inaczej rozumuje Ingarden, który przekłada ten fragment jako: „...same stwierdzenia (Positionen) (realności)...” (I. Kant, Krytyka czystego rozumu, przeł. R. Ingarden, Kęty 2001, s. 479). Być może Ingarden kierował się Piotrem Chmielowskim, który przełożył to bardzo podobnie: „...twierdzenia (realności)...” (zob.: I. Kant, Krytyka czystego rozumu, przeł. P. Chmielowski, Lwów 1904, s. 422).
} 